\title{
There is Only One Presumption of Innocence
}

\author{
Thomas Weigend
}

\section{Antony Duff's Broad Concept of the Presumption of Innocence}

Antony Duff, in his thoughtful and thought-provoking article, enriches traditional thinking about the presumption of innocence (PoI) by explaining that there is not just one presumption of innocence relating to the criminal process. Innocence, he claims, is presumed in different contexts with different meanings. This broad perspective, based on Duff's general concept of civility and responsibility as the basis of law in modern society, opens up new dimensions to the presumption of innocence and leads to a nuanced analysis of problems that have vexed lawyers well beyond the common-law world, for example, the general legitimacy of pre-trial detention and the issue of the continuing exclusion of 'ex-convicts' from certain rights and privileges.

Although I agree with most of Duff's conclusions, I don't think that an indiscriminate use of the label 'presumption of innocence' furthers rational analysis. It certainly has great rhetorical advantages to use this label: the presumption of innocence is universally recognized as a basic tenet of a fair criminal process, and it has consequently been enshrined in prominent international conventions. ${ }^{1}$ Basing one's argument on the presumption of innocence therefore makes one's conclusions appear irrefutable or at least adds considerable weight to them.

The universally ${ }^{2}$ high status of the presumption of innocence may be related to the fact that the meaning and the reach of the presumption are far from clear. One of the few matters that are beyond doubt is the fact that the presumption of innocence is not what it appears to be. The presumption of innocence is not a presumption, i.e., a conclusion drawn from a given set of facts. ${ }^{3}$ It is a legal presumption, for example, that a person is dead when he has been missing for a certain number of years, or that a child born by a married woman is the offspring of

1 See Art. 14(2) International Covenant on Civil and Political Rights; Art. 6(2) European Convention on Human Rights and Fundamental Freedoms; Art. 8(2) American Convention on Human Rights.

2 Anthony Duff, 'Who Must Presume Whom to be Innocent of What?', this issue, p. 173, raises the question whether the presumption of innocence may play a different role in civil law countries. I see no systematic difference in that respect between 'adversarial' and 'inquisitorial' systems of criminal procedure, even though the consequences that are being drawn from the presumption of innocence differ substantially from one jurisdiction to the other. For a comprehensive comparative overview, see Carl-Friedrich Stuckenberg, Untersuchungen zur Unschuldsvermutung (Berlin: de Gruyter, 1998), 11-438. See also n. 10 below.

3 See, e.g., Kenneth S. Broun (gen. ed.), McCormick on Evidence, 6th ed. (St. Paul: West, 2006), 572-74. 
the woman's husband. ${ }^{4}$ Such presumptions are conclusions from a given set of facts, they are based on general experience, and they can normally be rebutted in any individual case. The presumption of innocence, by contrast, is not based on a certain set of facts, and it is not derived from general experience - certainly the fact that someone has been accused of a crime does not typically indicate that he has not committed that crime. What we really do in the context of the criminal process is to pretend, against our experience, that a person who has been officially charged with a crime has not committed that crime. The law may have good policy reasons to create that fiction (of which later), but the presumption of innocence clearly differs from other (true) presumptions in that it has no basis in fact or human experience.

The presumption of innocence also does not say anything about a person's (general) innocence. As the context of the presumption of innocence in international instruments 5 indicates, the presumption concerns only a particular criminal charge that has been raised against the person, not his general good character.

It is at this point that Duff's approach differs from the mainstream. He proposes a more comprehensive concept of the presumption of innocence:

'(W)e can take a more relaxed approach, and talk of not one but many PoI: of different presumptions made by and about different people in different normative contexts, with different effects, defeasible in different ways. ${ }^{6}$

Duff's approach covers 'innocence' before, during and after a criminal process, both in relation to the state and its law enforcement agencies and in relation to 'all of us.' Duff names the latter aspect 'civic PoI' and thinks that it 'reflects the civic trust that we owe our fellow citizens.'

Duff acknowledges the fact that 'civic PoI' does not follow the same stringent rules as its legal, trial-related version. Outside the trial context (and even before the laying of criminal charges), Duff notes, 'we can operate with more nuanced varieties of PoI (...), and accept that they may be qualified by suspicion without being defeated. ${ }^{18}$ While this is certainly true, the existence of different 'nuanced varieties' of the presumption of innocence in Duff's concept raises two questions: first, are these variations similar in kind or are they categorically different from the traditional presumption of innocence? Second, even if the mainstream presumption of innocence and Duff's broader version have certain features in common, is it useful to call them by the same name?

4 Cf. $\S 1593$ German Civil Code (a child born within 300 days after the death of the mother's husband is presumed to be the child of the deceased husband).

5 See, e.g., Art. 14(2) ICCPR: 'Everyone charged with a criminal offence shall have the right to be presumed innocent ...' In this context, the 'innocence' of the person can only relate to the offence charged.

6 Duff, this issue, s. 1, p.172.

7 Ibid.

8 Ibid., p. 179. 
With respect to the first question, Duff makes this argument:

'... if we are to understand the significance of the PoI within the criminal trial, we must see it as an expression of deeper values that should structure the state's dealings with its citizens; and (...) since the question of whether we are criminally guilty or innocent bears on the treatment we can expect both from the state and from our fellow citizens in contexts well beyond the criminal trial, the PoI must be relevant in these other contexts too.'

The common denominator of the various elements in Duff's broad concept of the presumption of innocence, if I understand him correctly, is the trust that we owe each other. But that conceptual basis appears a bit weak for carrying as broad and heavy a concept as Duff's overarching version of the presumption of innocence. What exactly is the common element that might link the requirement of proof beyond a reasonable doubt for a criminal conviction ${ }^{10}$ to the 'trust in each other, and in ourselves, to be reason-responsive, ${ }^{\prime 11}$ and to certain measures of crime prevention $^{12}$ ? The question whether one can be assumed to have committed a crime in the past, and whether one may be expected to commit a crime in the future, are both somehow related to 'trust,' but they are so different in kind that it is not helpful to apply the same standards and criteria when trying to answer them, generally or in individual cases.

Others might be inclined to place greater confidence in the strength of Duff's broad concept. They might emphasize its indubitable virtue of showing that there may exist one common 'golden thread' of trust in the good character of citizens, which links our reluctance to treat fellow citizens as criminals before conviction to our reluctance of treating them as still dangerous after they have served their sentences. But even if one recognizes that golden thread, there remains the nagging question whether it is wise, as a matter of semantics and rhetoric, to employ the same term for concepts that even Duff concedes to be 'different presumptions made by and about different people in different normative contexts, with different effects, defeasible in different ways. ${ }^{13}$ By the broad usage proposed by

10 In common-law understanding, the presumption of innocence includes the notion that a certain standard of proof is necessary to overcome the presumption. The international legal instruments dealing with the presumption of innocence (see n. 1) do not mention that standard but require only that guilt should be proven 'according to law.' One can indeed make the argument that the necessary standard of proof can and should be treated separately from the presumption of innocence as such. For a persuasive argument in that regard see Stuckenberg, Untersuchungen zur Unschuldsvermutung, 522-30. That question is not of great importance because the standard of proof required for a criminal conviction is more or less the same in all legal systems. Differences exist, however, as to whether (and under what circumstances) the defendant can be made to bear a burden of proof or at least of persuasion with respect to certain facts, such as 'affirmative defences' under common law.

11 Duff, 'Who Must Presume Whom, p. 181.

12 Ibid., s. 3.

13 Ibid., s. 1, p. 172. 
Duff, the presumption of innocence is getting blurred and risks losing a precise meaning. Since the term 'presumption of innocence,' as I pointed out above, is by itself misleading, it adds to the confusion if one employs it for two (or more) ideas that are only marginally connected with each other.

\section{A Narrow Concept}

For these reasons, I would prefer to limit the term 'presumption of innocence' to its traditional meaning: a person charged with a crime is to be treated as if he had not committed that crime until the court has found him guilty. The presumption of innocence (in this narrow sense) thus comes into play only where an agent of the state has raised a suspicion that an individual has committed a criminal offence. In this situation, the presumption of innocence has an important function. The (frequently counter-factual) assumption that the suspect is not guilty is to protect the suspect from overbearing by the state and its agents. Why does the suspect need this protection? The very existence of an individualized suspicion of criminal wrongdoing has serious social-psychological consequences: it tends to stigmatize the suspect and to jeopardize his acceptance as a trustworthy citizen. ${ }^{14}$ At the same time, the rigours of the criminal process and the great social interest in determining the 'truth' about crime permit the state to restrict individual liberties to an extent that is unheard of in other instances of state vs. citizen confrontation. This combination of a reduced social status and the submission to the state's far-reaching powers leave the suspect in a particularly vulnerable position. There is a real risk that the state will use its vast procedural powers (e.g., to arrest and detain a suspect, to interrogate him, ${ }^{15}$ to provisionally seize his property) in order to start punishing him for the offence of which he is suspected, based on the common experience that the great majority of those who are suspected of a crime are indeed guilty. That same rule of experience is also likely to make state agents rush to a finding of guilt without a careful evaluation of the evidence.

It is against these risks that the presumption of innocence is meant to provide a counterweight. 'Assume that the suspect did not commit the crime,' the presumption tells the law enforcement official, 'and then ask yourself whether you can do to him what you intend to do.' By that standard, any interference with the suspect's rights is illegitimate unless it can be based on valid grounds distinct from any assumption that he is in fact guilty.

Given the fact that Duff thinks that the 'civil' variant of the presumption of innocence is subject to gradation, ${ }^{16}$ it bears emphasis that the presumption of inno-

14 In that regard, I am in full agreement with Duff.

15 I am aware of the fact that a suspect - at least in civilized legal systems - need not respond to inquiries, regardless of the presumption of innocence. But the presumption of innocence may have played an important role in reaching that status. It is certainly not by chance that the presumption of innocence and the freedom from forced self-incrimination have made their appearance at the same time. 
cence in the context of being a suspect or defendant in a criminal process is an absolute. A person, in this context, cannot be assumed to be 'a little guilty' or 'perhaps guilty'; if that were the case, the presumption of innocence would lose its salutary effect because it would open the door to applying 'a little' oppression.

One example of the operation of the 'narrow' concept of the presumption of innocence - and of its problems and limitations - is pre-trial detention. Curiously, Duff accepts the practice of bail but has great reservations against pre-trial detention as such. ${ }^{17}$ Yet, under the aspect of the presumption of innocence, pre-trial detention may be defensible as a means of protecting the integrity of the criminal process. If the law precludes - as it does in many jurisdictions ${ }^{18}$ - any trial in absentia, the defendant can sabotage the determination of the truth at trial by simply ignoring a summons to appear for trial. Preventing him from doing so is legitimate, to the same extent that the state may impose on a witness the duty to appear and to testify, and may even restrict the witness's liberty for that purpose.

The means that are necessary to safeguard the appearance of an uncooperative defendant at trial depend on the circumstances. In many cases, it may be sufficient to arrest him on the day of the trial and take him to the courthouse against his will. But the defendant may consider escaping from the court's jurisdiction; in that case, demanding a financial surety of him or imposing other measures (such as electronic surveillance devices linked to his body) may be sufficient for keeping him close by. But with suspects who have no money for bail, or who have so much money that they can easily jump bail, physical detention may be necessary to make sure that they will be present for trial. Since even defendants who are in fact innocent have a legal duty to appear for trial, these measures as such are guilt-neutral and therefore permissible. ${ }^{19}$ The fact that a suspect's freedom of movement may be restricted without violating the presumption of innocence certainly does not mean that the present practice of making liberal use of pre-trial detention, and of treating pre-trial detainees as harshly as (or even more harshly than) offenders sentenced to prison is legitimate. It should be clear from the explanation above that pre-trial detention may be used under only very limited circumstances; and the detainee deserves to be treated with the respect that any citizen deemed innocent deserves. Practice in many jurisdictions, regrettably, differs from that ideal.

But the real test comes when a legal system recognizes trials in absentia: ${ }^{20}$ Can we detain a person before trial just to have him present for imprisonment in case he is convicted, or can we confiscate a suspect's money to make certain that he will later pay a fine as part of his sentence? Logically, such preventive measures vio-

17 See ibid., p. 184-5.

18 See, e.g., $§ 230(1)$ German Code of Criminal Procedure: 'No trial will be held when the defendant is not present.' One may question the wisdom of this rule - there is in fact no good reason for forcing the defendant to be present, except his own interest.

19 The principle of proportionality sets certain limits to pre-trial detention, but that need not concern us here.

20 See, e.g., Art. 786(1) Spanish Code of Criminal Procedure. 
late the presumption of innocence - detention and confiscation are imposed only because we 'assume' that the suspect will be convicted. We can save the legitimacy of pre-trial detention under these circumstances only if we rely on a 'double suspicion' that the suspect (a) has committed the crime in question and (b) will not voluntarily comply with a judgment against him. Both come at least perilously close to a violation of the presumption of innocence.

When does the presumption of innocence (in a narrow sense) set in? According to Article 6(2) of the European Convention on Human Rights (ECHR), 'everyone charged with a criminal offence' shall have his innocence presumed. ${ }^{21}$ Duff, however, is concerned about the time span before the laying of charges: He demands that 'we should also be protected, before we become defendants, against the unwarranted imposition of the burdens of becoming a defendant - of being put on trial (...)'22 and wishes for 'a PoI that protects all citizens against having the burdensome normative role of defendant imposed on them, unless there is sufficient evidence of their guilt. ${ }^{23}$ Duff fears that one might be drawn into the criminal process and suffer a lengthy investigation without being protected by the presumption of innocence. To a certain extent, the European Court of Human Rights has accommodated that concern by adopting a broad definition of the words 'charged with a criminal offence': the protection of Article 6(2) ECHR, the Court proclaims, does not require a formal laying of charges but sets in as soon as the individual has been officially notified that he is alleged to have committed a criminal offence. ${ }^{24}$

But can the presumption of innocence protect citizens against being suspected of having committed a crime? If this is what Duff has in mind, then he expects too much of the presumption of innocence. It is important to remember that the fact that I am suspected of having committed a crime is not identical with a presumption of guilt. In fact, an official suspicion of criminal conduct and the presumption of innocence are inimical twins. Under the 'narrow' concept of the presumption of innocence, the existence of an 'official' suspicion (giving rise to the initiation of a criminal investigation) is indeed a necessary condition for the presumption of innocence to spring into action. As I pointed out above, the presumption of innocence is important exactly because the individual is under suspicion. The presumption limits the authority of the state in relation to a suspect: measures may not be taken against a suspect on the assumption that he actually committed the crime.

Beyond this restriction, the presumption of innocence is incapable of protecting a suspect against overly invasive investigative measures. There are other considerations at work to safeguard (more or less effectively) the liberty and property 
interests of suspects and other persons during the criminal process. The leading protective principle here is the principle of proportionality, which prohibits infringements of individual liberty where such infringements are not necessary for achieving a legitimate purpose or where their repressive effect exceeds that purpose. Two aspects of proportionality are particularly noteworthy here: First, the seriousness of the crime under investigation affects the permissibility of investigative measures, because the public interest in clearing up serious crime carries greater weight than the interest in discovering the truth about a minor offence. ${ }^{25}$ Second, the degree of suspicion against the suspect is a legitimate element of any proportionality analysis. The presumption of innocence notwithstanding, the fact that there are strong indications of guilt against a person may be sufficient grounds for imposing harsher pre-trial restrictions on him than on a person against whom only marginal suspicion exists. There are stronger reasons for demanding a person under heavy suspicion to respond to criminal charges against him than for interfering with the liberty interests of a person who may or may not have been involved in a criminal offence. Again, such gradations do not violate the presumption of innocence - even an innocent person can be expected to submit, for example, to certain invasive examinations of the body when there exist strong indications of his guilt and there is no other way to determine the truth. The demands on his liberty are made not because he is deemed guilty but because examining his body is the (only) means to determine whether he is guilty or not. ${ }^{26}$

Duff's concept extends the presumption of innocence well beyond the original trial: he claims that the presumption of innocence protects the individual even after the trial is over, both in case of conviction and of acquittal. Under the narrow concept of the presumption of innocence, by contrast, the presumption loses its effect once the criminal process has been concluded. The reason for the presumption's temporal limitation is the limited rationale of its existence: if the presumption of innocence is to protect the suspect against overreach while he is subject to the state's special powers during the criminal process, the presumption is

25 Because the seriousness of crime affects the weight of the public interest in discovering the truth, distinctions referring to the gravity of the suspected crime do not violate the presumption of innocence: a murder suspect is presumed innocent to the same degree as the suspect of a shoplifting offence; yet it may be legitimate, ceteris paribus, to impose pre-trial detention on the murder suspect and not on the shoplifting suspect.

26 Cf. Duff, this issue, p. 180. It has not become quite clear to me what Duff means when he refers to procedural 'roles' that confer certain burdens upon those who are to play those roles (see, e.g., pp. 179, 184). Certainly the fact that one is assigned the 'role' of defendant or witness does not by itself trump the civil rights of the role-players; nor should the assignment of any role be sufficient to pre-empt whatever civic version of the presumption of innocence may exist. 
no longer needed when the process is over. ${ }^{27}$ Because of that different understanding of the presumption of innocence, my conclusions regarding the posttrial phase differ from those proposed by Duff.

I concur with Duff in that the state may not place burdens on an acquitted (former) defendant in view of a prior or still-lingering suspicion; therefore, an acquittee cannot be required to pay the costs of his trial. But I do not completely agree with Duff's statement that an acquitted person cannot 'still be treated by the state (or by his fellow citizens) as a suspect' because the presumption of innocence has not been defeated. ${ }^{28}$ Since the 'narrow' presumption of innocence extends only as far as the criminal process, the suspicion (as an empirical phenomenon) may survive the process and may play a role in a different legal context. Contrary to what Duff claims, I think that other officials of the state are not precluded from treating an acquittee as a suspect. ${ }^{29}$ The reason for that limitation of the presumption of innocence lies in the fact that criminal courts may well speak for 'us' but do so with a limited mandate. Their sole function is to determine whether the defendant should be criminally punished for the offence charged. The trial process is limited to that issue; and it is, moreover, limited by certain rules of procedure and evidence that are specific to the criminal court's function. The truth-finding function of the criminal court may, for example, be restricted by procedural rules that block the judge from adducing relevant evidence on his own initiative, or by rules excluding even credible evidence because of the way in which it had been acquired. A civil court where the victim sues for damages is therefore not bound by an acquittal of the defendant in criminal court; and an administrative agency may refuse to grant an acquittee a weapons license based on the facts that gave rise to the suspicion of criminal wrongdoing. ${ }^{30}$ These courts and agencies are not bound by an acquittal because a determination of dangerousness must be made on the basis of the person's actual behaviour and often requires a lesser degree of certainty than a criminal conviction. It is a different question whether a court that later passes sentence on the acquittee for another crime may enhance his sentence due to 'recidivism.' ${ }^{31}$ That

27 The criminal process is terminated when the judgment has become final, or the case has been finally dismissed. Legal systems differ, however, with respect to acknowledging the presumption of innocence during the appeals process. Whereas in the common law tradition the verdict of the jury concludes the trial process and thus removes the protection of the presumption of innocence, the civil law tradition does not regard a conviction as final until all avenues of appeal have been exhausted or waived. The German Constitutional Court has nevertheless permitted a trial court to make an official statement that the defendant is 'guilty' even before the judgment has been rendered but after all evidence has been taken and the court has been convinced of the defendant's guilt; see Decision of 26 March 1987, 2 BvR 589/79, German Federal Constitutional Court, 74 Entscheidungen des Bundesverfassungsgerichts, 358 at 372-373.

28 Duff, this issue, p. 177.

29 But I fully agree with Duff, ibid., p. 178, in that public officials must not 'portray the acquitted defendant as guilty.'

30 But see, contra, Duff, ibid., p. 179: 'The court's presumption of the defendant's innocence is our collective presumption; the court's verdict that the presumption is undefeated is our collective verdict: it would be inconsistent for us, collectively, not to abide by that verdict.'

31 See ibid., p. 177. 
practice can be deemed legitimate only if the sentencing court has independently established the individual's guilt of the former crime, and if the applicable rules on double jeopardy permit the sentencing court to do so.

The presumption of innocence certainly does not restrict the freedom of citizens (including writers and journalists) to have and express their opinion as to the acquittee's guilt or innocence. Since the purpose of the ('narrow') presumption is to protect the suspect from the powers of the state, it does not extend to his fellow citizens, and therefore does not restrict media reporting on crime before and especially after trial. Any protection that exists in that respect must be based in civil (tort) law. Neither a suspect nor an acquittee has to tolerate allegations affecting his honour and reputation unless they are based on facts; but the media remain free to review and criticize a judgment of acquittal if they can adduce factual information or legal grounds that militate against the criminal court's conclusion.

\section{A Presumption Based on 'Civic Trust'?}

But what, then, about Duff's concept of 'civic trust'? Duff claims that we, as citizens, ought to presume each other to be innocent. ${ }^{32}$ From that proposition, he draws not only moral consequences but also legal ones, relating, for example, to the issue of restricting rights of ex-convicts. I will deal with these specific issues, but I first wish to comment on the legal or other basis of any presumption of future lawful behaviour.

As proposed by Duff, civic trust, as a socio-ethical principle of conviviality, may make life easier and less depressing. An optimistic attitude, assuming that others around me mean well, raises my spirits, whereas a lingering expectation that my fellow individuals may want to hurt or cheat me will make me equally circumspect and unhappy. But to expect that my fellow persons will abide by the law is an advice based on practical psychology, not an ethical or a legal obligation. Duff claims that 'we owe it to each other to recognize each other as fellow citizens: not to assume in advance that others are enemies who might attack us. ${ }^{33}$ But I doubt that we (as members of civil society) are morally bound to entertain a general presumption (or, I would rather say: an expectation) that everybody will respect the (criminal) law - a presumption that would preclude us from demonstrating ostensible distrust as to other persons' law-abidingness. Such a general expectation of lawful behaviour cannot be established on religious grounds, since most people no longer believe that man must be inherently good because God created him in His image. ${ }^{34}$ Today, the basis of any expectation of good conduct is as safe or shaky and as differentiated as our (cognitive) experience concerning people's

34 For a brief discussion of religious and philosophical sources of a presumption of innocence, see Stuckenberg, Untersuchungen zur Unschuldsvermutung, 494-96. 
behaviour. A general presumption that all people abide by the law at all times - as one could interpret Duff's article to proclaim - is certainly not based on experience, because experience (and criminological research) tells us that most people break some laws sometimes. Duff's proposition ${ }^{35}$ that 'we treat each other as agents who can recognize, and guide their actions by, appropriate reasons for action' fails to explain why we need to treat a person as a rational agent even if his conduct appears as irrational and/or immoral. Besides, it may be fairly rational for a destitute young man looking for drug money to rob a helpless old lady; and it may be less than rational to expect him to abide by the law in that situation. And even assuming that an obligation to trust one's fellow citizens exists as a matter of social ethics, how should it be turned into a legal rule? How should it be enforced? Surely the police cannot go around and forcibly prevent me from distrusting some or all of my fellow men.

'Civic trust' can only be understood as a concept of relative or gradated trust: a person may appear more or less prone to cause harm to others; he or she can be trusted under some circumstances, but not under others. Duff himself points out, quite correctly, that - without violating the rules of civic trust - a license to indulge in risky conduct such as driving a car may be revoked if the driver has demonstrated, through his past behaviour, that he can no longer be trusted to abide by the relevant law or to drive safely. ${ }^{36}$ If, by contrast, one regarded the 'civic' presumption of innocence as absolute until refuted, the question arises, first, what is required to overcome that presumption and, second and more importantly, what happens when the presumption of future goodness has been refuted. If it can conclusively be shown that I am not the law-abiding person that I was presumed to be, under Duff's theory, do I then lose all protection of the law and can I be preventively detained for long periods of time?

There exists, moreover, no social or normative need to postulate a general presumption of law-abidingness. There is no need because there exist other, more reliable and more specific normative devices that protect us against official overreach based on a suspicion that we may commit crimes in the future. The general basis of such norms is civil liberties and fundamental freedoms. The recognition of civil liberties, including a general freedom to act as one pleases as long as one does not interfere with the freedom of others, ${ }^{37}$ prevents the state from interfering with an individual's activities on the basis of nothing more than a general (or even specific) distrust of that individual. 'Civic trust' does play a role here: The basic liberty to act as one pleases is recognized only because we think that most people will not normally abuse that liberty in order to harm others. But that assumption is not absolute: restrictions of liberty are permissible, but my liberty may be restricted only if and to the extent necessary to protect others (or the 
community) from harm. This means that even if my general contempt of the law could be proved, any infringement upon my liberty would require a showing that I have concrete plans to do harm, and interference would have to be limited to what is necessary (and proportionate) to avert that harm.

The consideration that the desire to protect others from crimes that I am going to commit permits restrictions of my general liberty may help to resolve the puzzle of preventive pre-trial detention. ${ }^{38}$ If a judge orders a suspect to be detained before trial because the judge fears that the suspect may commit (further) crimes if left at large, that type of detention does not (at least: not directly) affect the presumption of innocence in a narrow sense, because detention is not based on the assumption that the suspect actually committed the crime he is suspected of. Rather, detention is ordered because there is a fear of future crime: the judge restricts the person's liberty in order to protect another, more significant interest, namely the integrity or fundamental rights of potential victims. Still, pre-trial preventive detention may be problematic because of a defective factual basis of the expectation that the detainee might commit crimes in the future. If, for example, $\mathrm{D}$ has been charged with raping $\mathrm{X}$ and denies the charge, and a judge orders D's pre-trial detention in order to stop him from committing further rapes before trial, then the 'factual' basis of that expectation may be nothing but the assumption that $\mathrm{D}$ in fact raped $\mathrm{X}$. To assume that $\mathrm{D}$ raped $\mathrm{X}$ before $\mathrm{D}$ has been convicted, however, clearly violates the presumption of innocence. In that case, an order of preventive pre-trial detention indirectly violates the presumption of innocence, because its only 'factual' basis is the assumption that the person is indeed guilty of the untried crime. Yet, this is not a categorical problem of preventive detention but only a matter of the sufficiency of evidence: if, for example, $\mathrm{D}$ denies raping $\mathrm{X}$ but credibly declares that he is now intent on raping as many women as possible before going to prison on a wrongful conviction, imposing pretrial detention on $\mathrm{D}$ may well be a legitimate measure.

Similar considerations may help to resolve the problem of the 'ex-offender.'39 I have argued above that the presumption of innocence does not extend beyond the end of the criminal process; if that is true, a person convicted and then released from prison cannot rely on the presumption of innocence in the narrow sense suggested here. The question then is whether the 'ex-offender' can at least rely on Duff's 'civic trust' version, that is, a general expectation that citizens will not commit crimes. Duff argues that it would be odd to insist on presuming of a responsible person that he is innocent of specific past crimes, whilst treating him as someone who is very likely to offend. ${ }^{40}$ But with all due respect I think that this statement contains a non sequitur: the fact that I have been acquitted of the charge of murder in 2011 says nothing about the likelihood that I will commit theft in 2013. Besides, being an 'ex-offender' is not a specific legal (or social) role, 
as Duff ${ }^{41}$ seems to suggest. Rather, it is part of one's personal history that one has been convicted of a crime and has served a sentence, in the same way as it may be part of a retired boxer's history that he was once world champion. One's personal history of crime should, as such, not have adverse social or legal consequences after one has served one's sentence. In that regard, statutes imposing certain disqualifications on all 'ex-convicts' are irrational, as Duff correctly points out. ${ }^{42}$ But this irrationality has little to do with any presumption of innocence; such disqualifications are irrational because they ignore a person's ability to change and also deny the offender the chance to be re-integrated into mainstream society.

It is a different question whether persons released from prison may, on an individual basis, be subject to certain measures of continued supervision, e.g., the denial of certain licenses, an obligation to register with the local police, or even continuing detention by another name. ${ }^{43}$ Here, as with pre-trial preventive detention, the past crime is only indirectly relevant, namely as one (but hopefully not the sole) indicator of the person's future dangerousness. Nor do we, as Duff ${ }^{44}$ claims, 'say to the person detained that we do not trust him at all - that we are going to treat him as a continuing enemy whom we detain for our own protection. ${ }^{45}$ As pointed out above, post-punishment restrictions of liberty can be legitimate only if there is a specific risk of crime that the state may (indeed, must) try to avert. It is another issue what are legitimate measures to avert a risk that can only be predicted with a large margin of error. But that is, again, a question of the proportionate restriction of liberty, and the presumption of innocence has nothing to do with it.

\section{Conclusion}

The presumption of innocence is a powerful rhetorical instrument. My concern is that it may lose its effect if we over-extend the concept. I therefore suggest a narrow definition of the presumption of innocence, limiting it to the protection of a suspect against specific dangers inherent in being subject to the powers of the state in the criminal process. All other issues that Duff raises may be resolved by employing a civil rights analysis.

41 Ibid., p. 186.

42 Ibid., p. 187.

43 See the infamous Sicherungsverwahrung (security detention) under $\S 66$ German Penal Code, which is being imposed after a convicted offender has served his full prison sentence, in light of his continuing dangerousness to others. For a thorough discussion of the legitimacy of this measure, see Decision of 4 May 2011, 2 BvR 2365/09, German Federal Constitutional Court, 128, Entscheidungen des Bundesverfassungsgerichts, 326.

44 Duff, this issue, p. 188.

45 The concept of Feindstrafrecht (criminal law of enemies), as cited by Duff, ibid., n. 59, has little to do with this issue. That concept assumes that some persons - especially members of certain terrorist groups - have on principle decided not to accept, and not to feel bound by, our legal order; see, e.g., Michael Pawlik, Der Terrorist und sein Recht (Munich: Beck, 2008). This is not the case with ordinary (recidivist) criminals. 